\title{
Analysis of Social Costs as a Result of Romanian Social Health Policy
}

\author{
Cristina Daniela Tomescu \\ Institute for Quality of Life Research \\ crisdobos@yahoo.com
}

DOI:10.5901/mjss.2014.v5n22p360

\begin{abstract}
The aim of this study is to discuss how social costs in health social policies can be evaluated. How can we measure implications of health policy decisions, embodied in what I have called social costs of these decisions? How can we measure which social groups are the most affected by current Romanian health policies? Among the social costs that we can intuitively detect are poor indicators of health status, poor indicators in distribution of services, accesibility and quality of medical services. Are these indicators enough to measure social costs in health social policies? 1
\end{abstract}

Keywords: Social costs, Health system policies, Health reform, Social Indicators, Measurement of indicators

\section{Introduction}

The health system in Romania has problems. It is a system that is funded by social contributions of only 4.5 million employees, but $90 \%$ of the population (18 mil.) has formal access to services, a large burden for the system. Health expenditure as percentage of GDP place our country on a final place among European countries, therefore the system is underfinanced. In these conditions, health system cannot insure high quality services for all the patients.Corruption in the system is also a factor that is leading to waste of resources to specific interest groups. There can be also detected exemples of ineffective management, bad health policy decisions, with medium and long-term consequences.

Healthy human capital is important for economic and social development of a nation. On the one hand, human capital in poor health negatively affects economic development by reducing work capacity and by increasing costs of providing public health services. On the other hand, economic development increases the living standard for the population, has impact on human health and on the resources available for investment in health services. We could say that in case of poor societies, there is a vicious circle between health status and health resources available in investing for health, but less healthy population, which unfortunately requires more investment. The circle could be broken by an additional effort of resources in the health system and consider long-term health policy as a priority.

Romania's accession made the reference point the health status and health services of European Union countries. Health of human capital in Romania is below the European average, with some problematic indicators such as high infant mortality, high tuberculosis morbidity. Conditions that are almost eradicated in developed countries of the EU, continues to affect a large number of Romanian (incidence of hepatitis $B$ is double, the incidence of Tuurbeculosis is one of the largest in the $\mathrm{EU}$, we have the highest rate of cervical cancer death in EU). Therefore, poor health is a problem with significant social implications, affecting employment and driving high social costs.

\section{Purpose of research}

My concerns on health policy issues in Europe and Romania dates back several years, including doctoral thesis in health social policy (december 2011). Meantime, I tried to answer some question: what would be the way forward for Romania in

\footnotetext{
${ }^{1}$ This proceeding is created within the programme co-funded by the European Union within the Operational Sectorial Programme for Human Resources Development, through the project "Pluri and interdisciplinary in doctoral and post-doctoral programmes", Project Code: POSDRU/159/1.5/S/141086
} 
reforming its health system and what path other European systems followed. I now ask myself which are the social costs that Romanian society pays as a result of poor health policies.

Problems for all national health services are put in terms of capacity of sustainability, accessibility, quality, waiting time, distance to health services, paying out of pocket for services. Continually rising cost of medical systems, aging populations, development of expensive innovative technologies are main concerns of all European governments.

I am interested in how can we measure social implications of health policy decisions in Romania, embodied in what I have called the social costs of these decisions and which social groups have been most affected by the health system.

At this stage, I have already constructed a research project in order to asses these evaluations of costs. The research will be developed during next 16 months, starting july 2014 that will gather field data, mainly based on a qualitative methodology.

I have proposed following objectives of research:

-Clearly define concepts I operate with : what is a social cost than other types of costs

-Identify types of social costs as a result of health policy

-Analyze how these costs were produced.

-Detect possible features of the health system that generated social costs.

-Detect indicators periods with developments that I can show certain costs of a type of measure / decision

-Identify social groups affected by these social costs than others.

-Identify how these groups perceive costs

-Identify weaknesses in the health system that generated and generates social costs.

-Identify whether health social policy conducted a long-term assessment of these costs? What indicators were used.

-Identify ways in which social policy makers perceive the costs

-Developed social policy recommendations based on the analysis results.

Research methodology includes three components:

- A secondary analysis of social data/social indicators

Possible social costs that can be highlighted by the development of socio-demographic indicators in the period 19902013:

$\square$ The evolution of socio-demographic indicators that characterize human capital: mortality, morbidity of various types, life expectancy, population growth, the rate of avoidable mortality attributed to healthcare.

$\square$ The indices of access to healthcare: distance to health services (on all 3 levels: family medicine / ambulatory / hospital) waiting time, number of services accessed.

\section{$\square$ indicator Evolution expenses / costs out of pocket for their health}

The evolution of service units

$\square$ The evolution of medical personnel in the system. The problem of social cost of migration of doctors as

$\checkmark$ Indicator confidence of population in the health system

$\square$ Indicator Evolution of satisfaction of population to health system

$\square$ The evolution of indicators characterizing social policy-ex. health expenditure as percentage of GDP

- A legislative analysis.

An analysis of the legislative history that regulated health system after 1990.

- A sociological research based on a qualitative methodology

Achieving depth interviews based on semi-structured interview guides with institutional and social actors:

\ People at risk: uninsured, unemployed, welfare recipients, people in poverty, people with disabilities or disabling/various disabilities and health problems, families with many children, low-income employees 


\section{จ health policy makers}

\section{1 doctors from family medicine / ambulatory/ hospital}

\section{ฉRepresentatives of trade unions}

$\square$ patients

\section{Theoretical Background. What is a social cost and how to measure?}

I have wondered what a social cost is and how it differs from other types of costs. A first definition of social cost would be a cost to society as a whole, as a result of an event, action, or policy change. It includes negative externalities, but it is rather a definition that comes from the economic field. (Source: Glossary of International Economics Deardoffs)

In conventional economics literature, social costs have externalities. They are understood as unplanned consequences of the activities of one or more economic agents which affect the well-being or productive capacity of others involved in the economic process, costs for which it is not possible to obtain or demand compensation. They has residual or secondary effects of the main economic activity of the agent, "external" effects and escape the working of the price mechanism. (Vitor Neves, 2012)

Policy implications of the current economic crisis led to social costs everywhere in Europe. (Wolfram Elsner et all, 2012). Capitalist market economy centered on money biased real social demands and needs. Although social costs can sometimes have a monetary component, they cannot be defined only in terms of money. They are not easy to be measured. Work, information (knowledge), institutions, there are commodities with a role to solve social problems. Social dilemma remains that between profitability and serving the individual or serving social. The social cost decreases quality of life, decreases the ability of democratic collective action. Social costs are preceding the crisis and they are also post-crisis. (Wolfram Elsner et all, 2012)

So how can we measure social costs as result of health policies? Among the social costs that we can intuitively detect are poor indicators of health status, poor indicators in equal distribution of services, accesibility and quality of medical services. Are these indicators enough to measure social costs in health social policies? I hope my project will answer these questions. Second data analysis, first hand data from qualitative research will answer to some questions related to types of indicators to be measured.

At this stage of the project, I made a list of possible indicators, easy to measure:

\begin{tabular}{|l|l|}
\hline $\begin{array}{l}\mathrm{Nr} \\
\mathrm{Crt}\end{array}$ & Type of Indicator \\
\hline 1 & Life Expectancy \\
\hline 2 & Life expectancy at various ages \\
\hline 3 & Life expectancy in good health \\
\hline 4 & Mortality \\
\hline 5 & Overall mortality \\
\hline 6 & Mortality by causes of death \\
\hline 7 & Survival rates \\
\hline 8 & Infant mortality \\
\hline 9 & Potential years of life lost \\
\hline 10 & Morbidity \\
\hline 11 & Specific morbidity; prevalence, incidence of some diseases \\
\hline 12 & Occupational morbidity \\
\hline 13 & DALY (Disability Adjusted Life Years) \\
\hline
\end{tabular}




\begin{tabular}{|l|l|}
\hline 14 & QALY - Economic evaluation \\
\hline 15 & $\begin{array}{l}\text { Indicators of lifestyle } \\
\text { Tobacco/ Alcohol /Drug /Diet indicators }\end{array}$ \\
\hline 16 & $\begin{array}{l}\text { Indicators for exposure to carcinogens and other hazardous } \\
\text { substances }\end{array}$ \\
\hline 17 & Frequency of occupational accidents and diseases \\
\hline 18 & $\begin{array}{l}\text { Indicators to characterize the environmental conditions } \\
\text { Exposure to carcinogens or other harmful substances from the } \\
\text { workplace }\end{array}$ \\
\hline 19 & Measuring the impact of premature death; \\
\hline 20 & Measuring avoidable deaths; \\
\hline 21 & $\begin{array}{l}\text { Development of composite indices that take into account both the } \\
\text { intensity of the phenomenon of death and non-fatal consequences of } \\
\text { the causes of disease (disability, handicap): }\end{array}$ \\
\hline 22 & Life expectancy without disability; \\
\hline
\end{tabular}

Adaptation after Georgeta Zanoschi, Indicatori de evaluare a stării de sănătate a populaţiei, 2013

If we look on figures for Romania, for these indicators, we can see that some health indicators have lower values than those of the European Union. For example, women in Romania has the highest rate of incidence and death from cervical cancer. This form of cancer is now preventable through early detection and cure, therefore a national screening program for cervical cancer is vital for Romania.

Another indicator for which Romania is positioned on the worst place in the European Union is infant mortality. Although still nearly two times higher than the EU average in 2010 , the infant mortality rate in Romania has decreased from values more than 3 times higher than the EU average in 2000. This may be due to both the effectiveness of national programs for maternal and child and growth of socio-economic level of the population of Romania in the last decade. Although most of the indicators have a favorable trend, since 1990, Romania has a lot of catching up to have a healthy population as the EU Member States, especially compared to EU-12.

\section{Research premises.}

Which are the premises that would reduce social costs? In this phase of theoretical framework, I am starting from a couple of premises regarding health policy decisions that could in my view, reduce social costs. These decision of social policies should theoretically lead to decrease of costs. I shall analyse these by qualitative methodology in my research, also legislative analysis and analysis of second data indicators.

A. Health Insurance system must should not be considered a luxury.

Health care should not be a luxury for some social groups, as it is today. Therefore, the need to find appropriate intervention mechanisms. Costs for the treatment of serious diseases outweigh the savings of middle class families, whether these costs should be paid out of pocket. Demand payment from pocket at the time of purchase care service leads in many cases to inability to pay for consumers and health becomes a luxury. Stomatologist services are a problem in Romania, because they are not covered bt helath insurance are very expensive for population. Therefore, a coverage with health insurance for stomatologist services is needed.

B. Health Insurance system must fulfill the function of shock absorption / social risks absorption, together with other components of the welfare state.

Transition stress, poverty, unemployment had direct impact on public health since 1990. System currently fails to reduce these shocks. It requires the establishment of a system of individual and collective risk absorption and redistribution of 
resources. Vertical redistribution aims to reduce inequalities, to secure equal access to services (education, health, social protection) and horizontal redistribution is designed to offset market failure situations and modern social risks. It is a matter of social morality that health insurance system should reduce the barrier between rich and poor in inequality of consumption of medical services. The rich continue to use medical services more than the poor and have better access to services in most European countries. In a weak health system provided by the state, rich appeal to the upper class private system that offers decent treatment. This private system is however inaccessible to the poor or socially excluded. Vulnerable groups who may be exposed imbalances in the supply of medical goods and services are those geographically isolated, people with disabilities or disabling health problems, families with many children, poor families, the unemployed, low-income workers .

C. Health Insurance system must evaluate corectly health care needs

When we speak of demand for health services, things are more delicate. Unlike buying any other consume product, people have little knowledge about what they are buying when they need health care. There is an asymmetric information between buyer and supplier. Even when they have a choice, patients choose between what the doctor suggests. Demand is therefore forced, unplanned, led by the doctor, not the consumer. (S. Bodenheimer T, Grumbach K, 2009)

The most important institution for treatment in Romania remains the hospital, with direct consequences on the health budget. A percentage of $40 \%$ of the budget expenditures are expenditures for hospitalization. (Source: National Health Insurance House, 2013).

Request for services must be guided. Romania is faceing a high percentage of hospitalisation, leading to higher costs for system. This has some causes. On the one hand, there is a poor offer of services of family medicine in some areas, on the other hand, some of the population seek medical help in advanced stages of the disease, so the concentration is higher for the university centers and hospital facilities. Some problems can be solved efficiently ambulatory. Treating a health problem that could be solved ambulatory reduce costs by up to 10 times than hospitalization. (Source: National Health Insurance House, 2013)

F. Health Insurance system must take into account that we have a large proportion of the rural population is poorly covered services

\section{G. Welfare state must mix efficiently medical assistance services and social assistance}

It is abnormal the translation to healthcare services of the social problems that should be solved by social assistance.Other alternative social care services should be developed: homeless shelters, relief and recovery at home, rehabilitation and counseling.

Examples of excessive use of medical for some social problems for which there is no other solution

-Hospitalisation of homeless persons especially in cold weather

- Hospitalisation of persons who actually need social assistance / help at home

- Early retirement from work through false disability certificates.

In modernity, we can find a supermedicalisation of modern life (Radulescu S, 2002), an increase in dependence of individuals to health care institutions. In medical units, all types of problems arrive: depression, suicide attempts, unwanted children abandoned in hospitals, homeless. Many of these problems have a social nature. Medicalization actually hiding their social origin unsolve the social inequalities and social anomie. Admission temporarily mask the individual's social functioning problems. Super-medicalization trend has increased health costs and the number of medical acts.

Treating the disease without taking into account complementary social policies is the wrong direction. For example, the doctor treats a poor man in Romania and is releasing the patient. The pacient returns to the same environment with poor housing conditions, no proper food, hygiene, money to continue treatment. The income from minum wage doesn't insure him proper resources. Such medical resources invested in that man may be ineffective as long as the entire social system does not intervene properly. It is an example that shows inefficiency handling of social problems.

$\mathrm{H}$. We need a coherent policy that ofeer shock absorption for private cost of health market. This is especially for drug market and stomatology market

There are health systems, areas where the market has a primary role. It is about supply and demand for drugs. Manufacturers of drugs, sanitary supplies and equipment are private entities. State intervention to reduce market impact is through compensation or covering of certain types of medication for patients. A case exploded in massmedia. In Romania, 
the state requires low prices on the sale of drugs. But the legislation did not protect patients properly. Cheap drugs were purchased before entering in pharmacies by "smart guys" and exported for profit. The cumulative effect is that patients are left without the necessary medication, and the profits go into the pockets of speculators: view cytostatic crisis, rapid morphine crisis (report IRQL, 2013). The state must intervene to stop such slippage.

\section{We need a depolitization of Health system.}

Health often becomes an object of political struggle. In each campaign, the parties raise the issue of health and the possibility of the state to ensure health expenditure. Medicine is part of a complex history, about power. According to the theory of social conflict (Radulescu, 2002), the medical system is seen as an institution of domination and power, the product of tensions and disagreement between groups with different interests. The social system gets to work better for privileged groups. Health institutions, pharmacies and doctors are dominated by two conflicting motivations: own financial profit or social interest.

\section{$\mathrm{K}$. We need to stop interest groups and conflicts of interest}

It sounds cynical, but the market economy and power structures for providing social justice issues, morals in health lost ground. The most striking case is that of pharmaceutical companies and pharmaceutical distributors that for maximizing profits, are leading campaigns to promote products to the patients and the doctors, or even "corrupt" doctors in the system through incentives such as payment of Congress or incentives to prescribe certain drugs to patients. Some doctors hide conflicts of interest that include: working at clinics, private laboratories, where they send the patients found in the public system.

\section{Co-payment in health system may increase social costs}

The introduction of co-payment is generally a measure to drop the pressure on those medical facilities where these payments are introduced. For example, the large amount of appeal to the Emergency Unit (UPU), which introduces high costs for the system.

Co-payment should be treated with care as means of adjusting, for they may affect people with low living standards, which could not afford the co-pament and decrease access to services.

"There are some classic examples of states that have decided to introduce co-payments for consultations and medicines; these states were later forced to review its decision, as it was observed a sharp increase in the use of emergency and hospital services. It turned out that these low-income patients were unable to afford co-payment for necessary care, and reported a worsening of their health because they did not receive timely medical care or pharmaceuticals. There was a worsening of health for the population group with chronic disease and/or poor general health condition as a result of avoiding necessary care. Another group at risk of not receiving medical care when needed, is the children of low-income families. "(Ciutan M., 2009, p 25)

\section{We need to increase funding and consider health care a priority}

Health policy analysis should be studied in the context of the social and historical background of the national health policy. Romania having low economic resources, gave the health system and education a marginal position as funding. At the same time, the policy of reforming the health system was not bold enough to achieve major reforms, as did other former eastern reforms and failed to improve services quality. Socio-political history, ideological values of each state and the role of unions or professional organizations modeled systems development.

Given the crisis in the period 2008-2013, all European countries have adopted pragmatic measures packages to meet the financial crisis, but not reconsidering the role of the state and its social functions. Measures aimed at reducing public spending and restrict / control of administration and increasing spending budget resources. Mature markets took into account tax reduction measures to stimulate economic growth. Former communist states went mainly on measures to increase taxation. We can not speak of a trend in terms of anti-crisis fiscal measures, each country taking decisions taht considered advantageous.

In the health sector as a result of the need to reduce budget deficits in many countries, governments face the difficult political choices in the near future. Governments may have to limit the growth of public health expenditure, to reduce spending in other areas or raise taxes or social security contributions to reduce deficits. On the other hand, improving the efficiency of spending in the health sector can contribute to controlling these pressures, for example through a more rigorous evaluation of health technologies and wider use of information and communications technologies. (OECD, 2010)

\section{$M$. There is a need for strategic planned decisions and not reactive responses}


Not everything is the result of government policies. When decision makers are faced with a crisis situation, they tend to adopt emergency solutions that bring temporary solutions and whose impact is not measured in the long term. (Crinson I., 2009). Decisions of the Ministry of Health of Romania were in many cases reactions to problems, answers reactive and not planned strategy decisions. See ambiguities at Romanian Law 95/2006, which governs the entire health system. It has been amended many times.

Health policy process is a pragmatic response to a range of health and social problems, based on a set of values. Public policy is the course of action or lack of action chosen by the public authorities in response to a specific problem or set of interconnected problems. Public policies offer a path forward for a range of interrelated actions. The definition also refers to the action and inaction provided to be selected by the authorities. Such policies are tools by which to solve community problems.

In the study of health policy, it is important a comparative analysis of health systems, otherwise we face the risk of studying an isolated system and see no commonality problems. Some problems are redundant in discussions about health policies:

$\checkmark$ The need for all health systems for effective organizational management and increase system performance in terms of cost / benefit, due to increasing health expenditure.

$\square$ The need to reform the health system: decentralization, privatization, public-private mix adoption (provided by the state, private and non-profit sector), with increased patient choice of provider.

口 Resistance organizational culture / institutional, professional medical organizations to change, to reform.

$\checkmark$ Critique of consumerism on the health care market and the issues of equity and access to services. None of the health systems have failed to reduce totally inequality in access to services. There are still groups in all the countries facing drawbacks. Most times, they are selected from immigrants, the poor, uninsured / unemployed, ethnic.

$\square$ Increased demand for long-term care in the community, which should lead to reform health and social services. We need a mix of social services with health in communities. A number of medical problems have an element of social anomie to be solved as a series of social problems have a health component: alcoholism, drug addiction, abandonment of children and the elderly, suicide attempts.

\section{Conclusions}

Conference communication will include analysis of first empirical data. I hope that feed-back from other collegues: sociologists, economists, other specialists will help me improve and consolidate my research projects. I have already constructed a research project in order to asses these evaluations of social costsThe research will be developed during next 16 months, starting july 2014 and will gather field data by a qualitative methodology on a sample of subjects including medical personell of different types, patients, health policy decision makers, representatives of medical trade unions. Also, the methodolohy includes second data analysis on social statistical indicators and legislation evaluation. The data collection starts August and September. So, there will be available first data to be presented at MJSS conference in September. This proceeding briefly included presentation of research project, some theoretical aproaches, work hypothessis and discussions related to the subject of research.

Other evaluations so far (Vlădescu, Ciutan, Dragmomirișteanu, Rădulescu) shows that education and health status of human capital was not considered at the level of social policy as priority of transition, despite declarations of principle. These is expected to have long term consequences on social development of Romania. Social inequality and polarization access to health services currently exist and the large differences between urban population (with access to health and education services in university hospitals) and on the other pole, rural population, with problems accessing services at the primary level and problems in moving toward the center services: heavy travel costs and distance to a population living from subsistence agriculture, with few financial resources available.

\section{References}

Dunn N. William, 2010, Analiza politicilor publice. O introducere, Editura Polirom, lași

Dragomirişteanu Aurora, 2011, Etica alocării resurselor în sistemul de sănătate din România, teză de doctorat, Universitatea de medicină şi farmacie, laşi 
Elsner Wolfram, Frigato Pietro, Ramazzotti Paolo, 2013, Social costs and Public Action in Modern Capitalism. Essays inspired by Karl William Kapp's theory of social costs, Routledge Frontiers of Political Economy

Elsner Wolfram, Frigato Pietro, Ramazzotti Paolo, 2012, Social Costs today. Institutional Analyses of the present crisis, Routledge

Fărcăşanu Otilia, 2010, Percepţia populaţiei asupra corupţiei, plăţilor informale şi introducerii coplăţii în sistemul public de sănătate din România, în Revista Management în sănătate, nr 1/2010

Karanikolos Marina, Mc Kee Martin, 2011, Cât de performant este sistemul de sănătate din România? în Revista Management în sănătate, nr 1/2011

Kozierkiewicz Adam, 2011, Will legal restructuring affect the real economy of hospitals? in Health Policy deveploment in Eurohealth, vol 15, no 2, 2011

Mackenbach Johan 2006, Report Health Inequalities. Europe in profile, EU, http://www.who.int/social_determinants/resources/european_inequalities.pdf, consulted May 2014

Mărginean loan, 2004, Proiectarea cercetării sociologice, Editura Polirom, lași

Rotilă Viorel, 2011, Calitatea vieţii profesionale şi tendinţa de migraţie a personalului din sistemul sanitar, Editura Sodalitas Vítor Neves, Social Costs: Where Does the Market End?, Revista Crítica de Ciências Sociais, 4 | 2012 : Issue no. 4

Vlădescu Cristian, Ciutan Marius, 2011, Medicina Personalizată- o nouă abordare în domeniul îngrijirilor de sănătate la nivel european, în Revista Management în sănătate, nr 2/2011

Zamfir Cătălin, 2004, 0 analiză critică a tranziției: ce va fi "după", Editura Polirom, lași

Zanoschi Georgeta, 2013, Indicatori de evaluare a stării de sănătate a populaţiei, http://www.scribd.com/doc/148251956/INDICATORI-DE-EVALUARE-A-STARII-DESANATATE, consulted June 2014

Raportul Stării de sănătate, România 2010, Institutul național de sănătate publică, Centrul național de evaluare și promovare a stării de sănătate

http://ec.europa.eu/health, consulted June 2014

http://www-personal.umich.edu/ alandear/glossary, Glossary of International Economics Deardoffs, consulted June 2014 